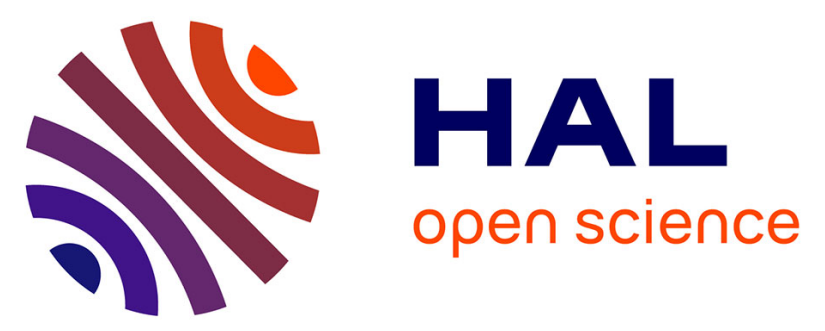

\title{
A Comparative Study of Two Mediterranean Transhumant Systems and the Biocultural Diversity Associated with Them
}

Pablo Domínguez

\section{- To cite this version:}

Pablo Domínguez. A Comparative Study of Two Mediterranean Transhumant Systems and the Biocultural Diversity Associated with Them. Mauro Agnoletti; Francesca Emanueli. Biocultural diversity in Europe, 5, Springer Verlag, pp.105-122, 2016, Environmental History, 978-3319263137. 10.1007/9783-319-26315-1_5. hal-02157640

\section{HAL Id: hal-02157640 \\ https://hal-univ-tlse2.archives-ouvertes.fr/hal-02157640}

Submitted on 17 Jun 2019

HAL is a multi-disciplinary open access archive for the deposit and dissemination of scientific research documents, whether they are published or not. The documents may come from teaching and research institutions in France or abroad, or from public or private research centers.
L'archive ouverte pluridisciplinaire HAL, est destinée au dépôt et à la diffusion de documents scientifiques de niveau recherche, publiés ou non, émanant des établissements d'enseignement et de recherche français ou étrangers, des laboratoires publics ou privés. 


\title{
Chapter 5
}

\section{A Comparative Study of Two Mediterranean Transhumant Systems and the Biocultural Diversity Associated with Them}

\author{
Pablo Domínguez
}

\begin{abstract}
The alliance between the natural and social sciences has proven to be a successful analytical approach to understand and conserve ecosystems worldwide, while seeing humans as key agents within these (1971 Man and the Biosphere Programme, 1972 Stockholm Declaration, 1992 Rio Conference). In this context, authors from various areas of expertise have stressed the importance of recognizing the inextricable link between biological and cultural diversity and the need to raise awareness of these interactions for global sustainability. Despite scientific research repeatedly insisting on the importance of such a link, there remains a gap calling to highlight the concrete ways in which this diversity of long-held biocultural relations manifests and is generated. In fact, many of the works demonstrating the aforementioned bond are focused on the bioecological consequences of human diversity. At the same time, when they introduce a more sociocultural focus, they most often make linguistic indexes, their main measure for culture and/or use quantitative and macro-geographical approaches. In this sense, the general trend of this type of works, although always valuable, seems somewhat reductionist or incomplete. A less hard science and more detailed ethnographic-humanist analysis of this diversity and its groundings are still lacking. In order to address the exposed problem, I will present my preliminary works comparing agro-pastoral transhumant systems of the High Atlas of Marrakech and the Central Spanish Pyrenees. The ultimate goal is to push for an increasingly holistic approach to biocultural analysis including the humanities to a greater extent, and a broader spectrum of the social sciences.
\end{abstract}

\footnotetext{
P. Domínguez

Laboratory of Socio-Ecological Systems in the Globalization (LASEG), Institut de Ciencia $\mathrm{i}$ Tecnologia Ambientals (ICTA), Universitat Autònoma de Barcelona, 08193 Bellaterra (Cerdanyola del Vallès), Spain

P. Domínguez $(\bowtie)$

Departament de Antropologia Cultural i Història d'Amèrica i Àfrica, Universitat de Barcelona, Montalegre 6-8, 08001 Barcelona, Spain

e-mail: eco.anthropologies@gmail.com
} 
Keywords Biocultural diversity - Agropastoralism - Transhumance - Commons • Pyrenees - High atlas

\subsection{Introduction}

The outcomes of biocultural diversity (Maffi 2005), particularly in traditional agro-sylvo-pastoral systems, have been critical throughout history for creating resilient landscape patterns (Gómez-Baggethun et al. 2010; JP-BiCuD 2010) and shaping ecosystems (Alaoui 2009; Fillat et al. 1995) as well as very particular cultural identities of different regions (Mahdi 1999; Pallaruelo 1988). This is especially true for the Mediterranean region (McNeil 2003; Vidal and Castán 2010). The particular geography of this area, defined by a sinuously shaped inland sea surrounded by an enormous variety of mountain ranges (Braudel 1949), favours in fact great ecological and cultural diversity, which implies an immense heritage of plants, animals and other living beings, as well as an enormously varied range of agro-pastoral techniques, customs, beliefs and social relationships. But this diversity is not only a result of the millenary derivatives and adaptations to local and particular conditions favoured by such compartmented systems. It is also the consequence of direct and indirect millenary exchanges between some of the most important farming civilisations in human history (Barbera and Cullota 2012). Due to this, the different agro-sylvo-pastoral management modes of the Mediterranean region share important similarities while they also have important specificities related to each particular biophysical conditions and each particular history. This makes them elements with (1) common grounds and (2) unique differentiated systems with their own biological and cultural diversity, intertwined through long-held biocultural transformations. Indeed, it is precisely through a specific process of trial and error instigated by the local communities, in direct or indirect connection with other populations over the centuries and millennia of Mediterranean relations, that the different and original communal management systems have been established in each case. Based on the scarcity and need for detailed ethnographic comparative studies on biocultural diversity, and the long-term field-experience accumulated by the author in Mediterranean transhumant systems, the present work will focus on the comparative analysis of two general models of such systems within two mountain areas of the Mediterranean bioregion where many different transhumant systems are still operating: the southern side of the Spanish Central Pyrenees and the northern rim of the Moroccan High Atlas of Marrakech, both covering an extension of approximately $100 \mathrm{~km}^{2}$ (Fig. 5.1).

Transhumant modes of herding seem to have been widespread throughout the entire Mediterranean region (Chassany 2008), which has been subjected to long-term agro-pastoral uses since at least $8000 \mathrm{BC}$ in the Fertile Crescent and 5000 $\mathrm{BC}$ in the Iberian Peninsula and the Maghreb (Rasse 2008). Nevertheless, 




Fig. 5.1 Map with the two areas of study marked in red, the Spanish Central Pyrenees and the Moroccan High Atlas of Marrakech

transhumance has slowly faded away from most plains up to the point that today they are mainly present in its mountain systems, where industrialization and private/state appropriation of collective land has had a lower historical incidence than in the plains. Located in sites which are often considered hot spots of endemism at a global level (Mittermeier 2004), the highland pastures object of transhumance, many times managed commonly, host in general a significant biodiversity due to the isolation effect that mountain areas produce as well as to the consequence of pastoralist activity and transhumance (Auclair and Al-Ifriqui 2012; Dominguez and Hammi 2010; Fillat et al. 2007). In purely agronomic terms, the key element of these transhumant systems in the two regions consists of a regulation of access to altitude grassland that prevents shepherds from allowing their animals to graze for three or four months. This period mainly coincides with the respective springs, which is the moment of maximum growth and reproduction of pastoral vegetation. This regulation is established and implemented by an assembly of users, both in the case of the Atlas and the Pyrenees. The purpose of such regulation is to ensure the regeneration and sustainable use of the common meadows, as well as to provide equal access to the different shepherds as they all access the pasture at the same time, and they jointly decide their ways and rules of management. However, as we will see below, these mountain commons are also a total social fact in the sense defined by Mauss (2012), around which revolves a whole system of social, economic, political, ritual and symbolic relations driven 
through the figure of the Mediterranean saints (Muslim in the Atlas and Christian in the Pyrenees). This fact makes transhumance a faithful reflection of two "connected" (Chassany 2008) and at the same time "particular" mountain cultures (Dominguez 2010; Beltrán 1993).

In short, the two regions of study seem both to converge within a certain general framework, at the same time as to diverge due to socio-historical and bioecological differences, turning them into a Mediterranean common heritage and an example of difference and particularity. It is in fact this tension that will be the guiding thread throughout the entire text, the final objective of which is to give some preliminary steps towards gaining a more complete and holistic understanding of the complex essence of the biocultural diversity. In fact, since many of the works studying and demonstrating the biocultural bond are either focused on the bioecological consequences of human diversity (Hammi et al. 2007; Sirami et al. 2010), or they make linguistic indexes their main measure for culture (Sutherland 2003; Stepp et al. 2005), using mainly quantitative and macro-geographical approaches (Zent 2001; Loh and Harmon 2005), it seems necessary to include a broader spectrum of social sciences and humanities.

\subsection{Convergences and Divergences}

The northern watershed of the Marrakech High Atlas and the southern watershed of the Central Pyrenees have certain analogies in biophysical terms, concerning certain botanical formations that are partially similar, such as supra-Mediterranean forests and scrublands dominated by holm oak (Quercus ilex), prickly juniper (Juniperus oxycedrus) and gum rockrose (Cistus Ladanifer). But what probably brings them closer in terms of the biophysical substrate of their corresponding transhumant systems, are the highland pastures that exist above the line of tree growth and that are one of the common key elements for the sustainment of these systems. Nevertheless, this pastoral frontier where the presence of meadows becomes dominant, diverges somewhat. It can be located at around $1800 \mathrm{~m}$ above sea level in the case of the Pyrenees, when in the Atlas it is at about 1900-2100, depending on the intensity of human pressure. At the same time, although certain general biophysical similarities exist, the Marrakech High Atlas highland pastures receive a much lower annual pluviometric average $(500-700 \mathrm{~mm})$ that can be up to two or three times higher in the Pyrenean high pastoral plateaux (1000-2000 mm). There is also a considerable difference of almost $10{ }^{\circ} \mathrm{C}$ in the annual mean temperatures between the oro-Mediterranean pastures of the two areas. And nevertheless, they have both attracted the attention of shepherds for the same reason (cyclically available fresh summer pastures) since pre-historic times (Rodrigue 1999; Mazzucco 2012). In these high places indigenous populations saw a complementary, abundant and nutritive resource for their flocks during the dry periods of the Mediterranean temperate climate zone that usually left the lower lands dry and unproductive in comparison to these alpine meadows. The economic importance of 
such sites became obvious for these populations at very early stages of the Neolithic and even the Mesolithic. It became so important in fact, that these spaces became centres of great symbolic meaning for pastoralist and proto-pastoralist populations. The outstanding presence of rock art that exists in both regions bears witness to this importance. Nevertheless, the convergence in this arena seems to stop mostly in the generic symbolic importance given to these highland pasture areas, since this importance is expressed very differently according to where we place ourselves. In the High Atlas they take the form of rock carvings where they are the norm, whereas they are rather rare in the case of the Pyrenean high pastures (Clot 1974) being megalithic art much more dominant.

\subsubsection{Rock Art}

The abundance of rock carvings found in the high transhumant plateaux and on the paths of shepherds in the Marrakech High Atlas is the proof of to the antiquity of the transhumant use of highland pastures. These carvings date back to between 2500 and $3500 \mathrm{BC}$, although it is important to mention that the drying up of the Sahara between 2500 and 1200 BC would have accentuated the sense of refuge of these mountain pastures, leading to an increase in the production of these both ritual and artistic manifestations (Rodrigue 1999). This dating and these carvings reveal the existence of an ancient transhumant society, essentially based on pastoralism due to the great dominance of pictures linked to animal-rearing activities above agriculture, particularly cattle, which in any case already coexisted closely with agriculture (Sellier 2004; Pascon 1983; Bellaoui 1989). In the Oukaïmeden and the Yagur where Mahdi (1999) and myself (2010) described fertility rites associated with the opening of the highland pastures, authors such as Simoneau (1967) and Auclair and Al-Ifriqui (2005) defend a certain continuity of these practices in these same sites since the paleo-Berber shepherds from the Bronze Age (2000-500 BC), from whom the abundance of symbols carved on the red sandstone of these pastoral centres (fish, moons, fibula, anthromorphic scenes of procreation and childbirth) remain.

On the contrary, in the Pyrenees, rock carving is very scarce, and consequently, quite unknown (Clot 1974). However, megalithism, which is practically absent in the Atlas, can be stated to have an overwhelming presence in the case of the Pyrenees. It has even been pointed out as evidence for the existence of a single and powerful nucleus of cultural identity throughout the whole mountain range until the second millennium BC (Almagro 1942, p. 169). This has often been explained as the influences of a clear continental-European inspiration, which has always pushed towards the South and had a powerful influence on the pre and proto-Neolithic people of the Pyrenees, counteracting the influences from the rest of the Iberian peninsula, and decanting the link of the Pyrenees Mountains towards the influences of the North represented by megalithism (Jiménez 2006). Later on, from the Iron Age onwards, the growing influence and establishment of Celt populations during 
the last centuries of the second millennium $\mathrm{BC}$ is understood as the process that caused the end of the megalithic culture of the Pyrenees (Maluquer 1987, p. 44). Nevertheless, this influence, again from the North, injected new differences between the two models of cultural expression. Thus, although the African and European models continued to be based on various similar ecological typologies and uses of natural resources (mountain pastoralism in Mediterranean climates), the different cultural influences made Maghreb rock art last for a great time longer (until approximately $500 \mathrm{BC}$ ) and in a very different way than in the Pyrenees.

\subsubsection{Transhumance, Between Agricultural Systems and Highland Pastures}

In both cases, the Central Pyrenees and the Marrakech High Atlas, the main habitat and the farmland are located in what we could call "the villages", generally at mid-altitude between the high summer pastures and the lower winter valleys and plains. However, this means slightly higher in the High Atlas (on account of their lower latitude), and slightly lower in the Pyrenees, due to the limiting factor of the temperatures at this same altitude. Depending on the community observed, in the High Atlas of Marrakech "the villages" are located at between 1000 and $1800 \mathrm{~m}$ above sea level, while in the Pyrenees they are rarely higher than 1200-1300 and start even at $600 \mathrm{~m}$, or even lower. Nevertheless, in all cases, through similarity in the type of natural resource and the exploitation techniques available, the traditional model of organization essentially coincides between the two areas and always revolved around the main village which became the centre of gravity of a double transhumance: one "normal" or "vertical" in summer, on the high pasturelands, and the other "inverse" or "horizontal" in winter, on the large steppe plains. ${ }^{1}$ However, in both cases, today, transhumance towards the plain is maintained at a residual level. Only some owners of the biggest flocks are interested in doing it today, since the travel costs are only offset if a large number of animals is mobilized, and this generally concerns only sheep. The fundamental reason for this alteration of winter movement seems to coincide in this case. In both Morocco and Spain, plains are increasingly owned by landlords, notably by owners of large estates or by large cooperatives, and therefore are occupied by crops in winter and spring, often even blocking the paths to them, meaning that transhumance no longer finds its place in these spaces and cannot be exercised as it was before.

In any case, although transhumance is increasingly bereft of its winter movement, the two transhumance models continue to make part of a vast mountain agricultural system. This is based on two principles: on the one hand, the integrated complementarity of the agricultural and pastoral productions, and on the other, the vertical

\footnotetext{
${ }^{1}$ In the case of the southern watershed of the Central Pyrenees, the flat lands of the Ebro; in the case of the northern watershed of the Marrakech High Atlas, the plains of the Haouz.
} 


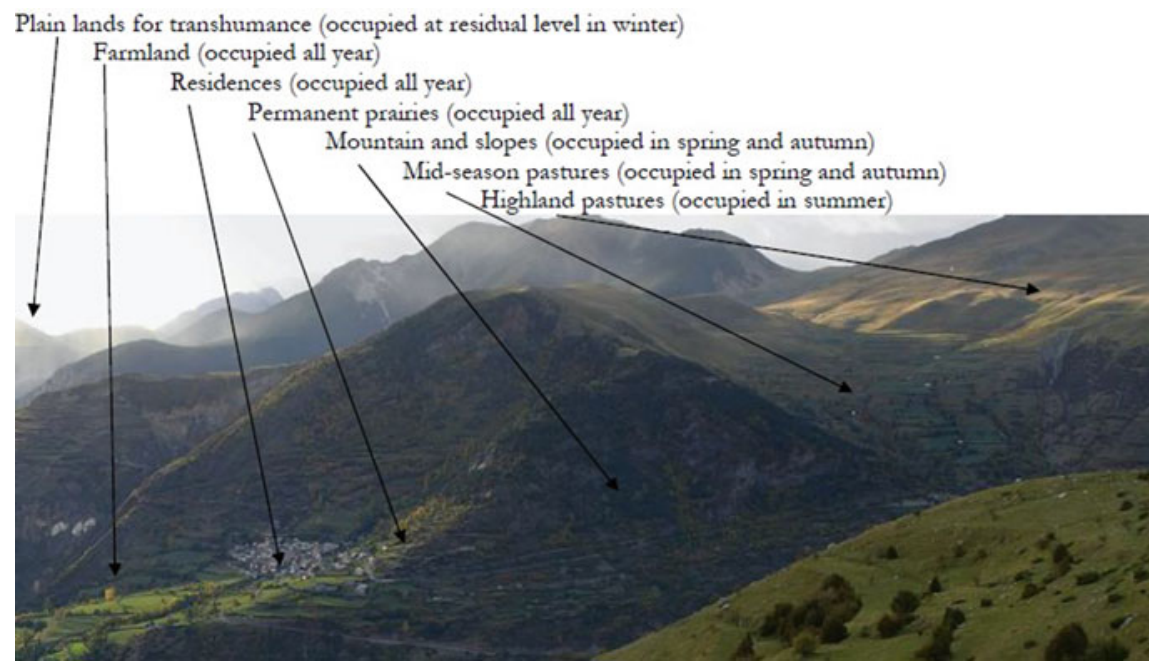

Fig. 5.2 General image of the use of space by agropastoralists in Gistain (Spanish central Pyrenees), in the Central Pyrenees and which corresponds directly to the model used in the High Atlas

complementarity of the spaces belonging to different bioclimatic stages. The integrated complementarity of animal and plant productions means that the animal-breeding provides manure for the crops and farm animals to carry out ploughing and threshing, and in return, the animals rely on crop products (e.g. barley, corn or fodder) for complementing their feeding, particularly in winter when pastoral resources are scarcer. At the same time, the vertical complementarity refers to farmers' use of the pasturelands belonging to diverse bioclimatic stages. As shown in the diagram below, shepherds combine the use of several spaces: (1) in winter, the plains and in the last decades increasingly the edges of the village; (2) in the intermediary seasons (spring and autumn), the mountains and their slopes; (3) in summer, the highland pastures (Fig. 5.2).

In both the Pyrenees and the High Atlas, transhumance highland pastures are located as a continuation of the main village lands, generally at a maximum distance of a half-day walking from the village houses. In fact, highland pastures which are used for transhumance find their place in a greater agro-pastoralist system. In other words, they are only part of a wider system and their use falls within a global and collectively rationalized use of the communal lands. And yet, highland pastures do not only contribute to the functioning of the local terraced systems by providing to the general production of the farm activity simply some "extra" fodder; but, in addition to providing very nutritional grasses for the animals (probably the richest of the whole annual cycle), these pastures provide food on site (i.e. without any need for transport or external inputs, and therefore at a very low cost), at an absolutely critical time in the pastoral cycle, and this is what is most crucial. That is, when the spring routes of the animals and the summer heat have finally exhausted 
the lowlands, leaving little to eat for the herds. It is important to note therefore, that the fodder contribution of the highland pastures comes at a strategic time, when the majority of other pastoral areas no longer have anything to offer, and the opportunity cost of such a resource is particularly high. Their participation in the animals' diet is therefore crucial, because it guarantees the "continuity" of the agro-pastoral system as a whole.

The above reveals what the different transhumant systems share regarding the economic role played by these highland pastures. However, as regards the productivity and composition of the highland pastures, they differ from one site to another as a result of the biophysical conditions and the different ways of management established in each site (Dominguez et al. 2012). In a first physico-technical definition, these highland pastures could be defined as homologous systems, altitude pastures with no trees, humid areas exposed to extreme conditions where grass grows in abundance in the spring thanks to the collection of water after the snow melts and the temperatures rise. But if we look in greater detail, more important elements related to the subject of biocultural diversity are at play.

In both cases, there is a practice of excluding animals from the pastures apart from some summer months, to maximize production and to guarantee the durability of the exploitation of the resource. This allows only the product of the year to be taken, and thereby saves the seeds for the following years. Several ecologists have underlined the particularly beneficial effects of this practice on the plant cover and the conservation of the local biodiversity (Auclair and Al-Ifriqui 2012; Fillat et al. 2007). But in fact, this exclusion of animals from the pastures, and the particular means of managing them in each case (essentially linked to the histories and needs of each socio-ecological context), not only enables species for pastoral use to be regenerated, but also "those" species which are more sought-after in each community, depending on the types of animals raised, and other additional resources used by each community, etc. For example, Alaoui (2009) confirmed this capacity of local ecological knowledge by demonstrating, through several tests that the majority of plants defined by the shepherds as most useful and beneficial for their animals on the pastures of Oukaïmeden in the High Atlas, reach maturity and drop their seeds after reproduction precisely a few days or weeks before the opening of this space to rearing, enabling the reproduction and conservation of a specific botanical community year after year. Human rationality and biological logics therefore meet as there is an intentional choice of species through a certain set of managerial habits that leads to very precise systems of plants. Table 5.1 shows the particular case of the pasture of the Yagur in the High Atlas, managed by the Mesioua tribe.

\subsubsection{Architecture}

As we have seen, the transhumance model affecting the different populations in the Pyrenees and High Atlas involves the splitting in two main areas: that where people usually live and that where they practice transhumance temporarily. The main 
Table 5.1 Species sampled in three different sites of the Yagur High Atlas pastures managed by the Mesioua community (Dominguez and Hammi 2010)

\begin{tabular}{|c|c|c|}
\hline ASSAGOUL & TAMADOUT & ZGUIGUI \\
\hline $\begin{array}{l}\text { Most external site of the } \\
\text { Yagur }\end{array}$ & $\begin{array}{l}\text { Intermediate site of the } \\
\text { Yagur }\end{array}$ & $\begin{array}{l}\text { Most internal site of the } \\
\text { Yagur }\end{array}$ \\
\hline Species: 54 & Species: 59 & Species: 66 \\
\hline Alchemilla atlantica & Allium roseum & Allium roseum \\
\hline Allium roseum & Alyssum serpylifolium & Alyssum serpyllifolium \\
\hline Alyssum serpylifolium & Avena sterilis & Alyssum spinosum \\
\hline Asphodelus microcarpus & Bromus madritensis & Androcymbium graminum \\
\hline Astragalus maroccanus & Bromus tectorum & Asteriscus pygmaeus \\
\hline Avena sterilis & Carlina involucrata & Bromus madritensis \\
\hline Bromus madritensis & Carthamus lanatus & Bupleurum semicompositum \\
\hline Campanula dichotoma & Catananche caerulea & Calendula aegyptiaca \\
\hline Campanula trichocalycina & Catananche caespitosa & Campanula rapunculus \\
\hline Carduus pycnocephalus & Centaurea sulphurea & Carex divisa \\
\hline Catananche caespitosa & Cirsium casabonae & Catananche caerulea \\
\hline Cephalanthera longifolia & Cirsium syriacum & Cephalanthera longifolia \\
\hline Cirsium syriacum & Crepis vesicaria & Ceratocnemum rapistroïdes \\
\hline Coronopus procumbens & Dactylis glomerata & Cirsium monspessulanum \\
\hline Dactylis glomerata & Dianthus lusitanus & Cirsium syriacum \\
\hline Dianthus lusitanus & Echium pustulatum & Crepis vesicaria \\
\hline Diplotaxis assurgens & Erodium gruinum & Crucianella angustifolia \\
\hline Erodium gruinum & Erodium praecox & Dianthus lusitanus \\
\hline Erodium praecox & Erodium tordyloïdes & Echinops spinosus \\
\hline Eryngium ilicifolium & Eryngium ilicifolium & Emex spinosus \\
\hline Festuca elatior & Galium aparine & Erodium gruinum \\
\hline Festuca maroccana & Genista hirsuta & Eryngium ilicifolium \\
\hline Filago pygmaea & Gladiolus segetum & Festuca maroccana \\
\hline Galium aparine & Hedypnois arenaria & Filago pygmaea \\
\hline Geranium dissectum & Hordeum murinum & Galium aparine \\
\hline Geranium rotundifolium & Koeleria vallesiana & Gladiolus segetum \\
\hline Helianthemum croceum & Leersia hexandra & Hedypnois cretica \\
\hline Hordeum murinum & Leontodon hispidilus & Helianthemum croceum \\
\hline Koeleria vallesiana & Lotus creticus & Hierarcium pseudopilosella \\
\hline Koelpinia linearis & Mantisalca salmantica & Hordeum murinum \\
\hline Lotus creticus & Mentha pulegium & Hypecoum procumbens \\
\hline Mantisalca salmantica & Nonea vesicaria & Koeleria pumila \\
\hline Ononis spinosa & Oropetium africanum & Koeleria vallesiana \\
\hline Pallenis spinosa & Paronychia argentea & Koelpinia linearis \\
\hline Papaver rheas & Plantago coronopus & Lasiopogan muscoïdes \\
\hline Paronychia argentea & Plantago lagopus & Lepidium sativum \\
\hline
\end{tabular}


Table 5.1 (continued)

\begin{tabular}{|c|c|c|}
\hline ASSAGOUL & TAMADOUT & ZGUIGUI \\
\hline Plantago coronopus & Plantago major & Lotus arenarius \\
\hline Plantago ovata & Plantago ovata & Mentha pulegium \\
\hline Poa bulbosa & Poa bulbosa & Miniuartia tenuissima \\
\hline Reseda luteola & Rumex crispus & Minuartia geniculata \\
\hline Rhaponticum acaule & Salvia verbenaca & Paronychia argentea \\
\hline Rumex crispus & Scorzonera laciniata & Phalaris minor \\
\hline Senecio vernalis & Scorzonera pygmaea & Plantago coronopus \\
\hline Silene cucubalus & Senecio gallicus & Plantago lagopus \\
\hline Silene gallica & Senecio vulgaris & Poa bulbosa \\
\hline Sonchus asper & Silene apetala & Ranunculus aquatilis \\
\hline Sonchus tenerimus & Siybum marianum & Ranunculus spicatus \\
\hline Stipa retorta & Sonchus asper & Reichardia tingitana \\
\hline Teesdalia nudicaulis & Sonchus tenerimus & Resada battandieri \\
\hline Urginea maritima & Stipa nitens & Rumex crispus \\
\hline Vulpia ciliata & Stipa retorta & Rumex vesicarius \\
\hline \multirow[t]{14}{*}{ Vulpia geniculata } & Teesdalia nudicaulis & Salvia verbenaca \\
\hline & Thymus pallidus & Scorzonera undulata \\
\hline & Trifolium campestre & Senecio vulgaris \\
\hline & Trisetaria pumila & Sonchus tenerrimus \\
\hline & Urginea maritima & Stipa retorta \\
\hline & Urginea undulata & Thymus pallidus \\
\hline & Vicia onobrycoüdes & Trifolium campestre \\
\hline & Vulpia ciliata & Trifolium repens \\
\hline & & Trifolium tomentosum \\
\hline & & Urginea maritima \\
\hline & & Urginea undulata \\
\hline & & Vallerianella microcarpa \\
\hline & & Vicia dasycarpa \\
\hline & & Vulpia ciliata \\
\hline
\end{tabular}

settlement is always in "the villages" as we pointed out before, where the main croplands for the families is located, as well as where the more solid buildings which are, this is, their houses. The secondary settlement is generally in higher lands, marked by much smaller and more precarious settlements known as azibs in Morocco and majadas or bordas in Spain. The existence of these two main conceptual spaces, involves the splitting of the group and the family between those who practice transhumance and those who stay close to the croplands. These constructions supporting transhumance range from restored cave-like structures, to sheepfolds or little houses, and small isolated dry stone constructions, the nature and quality of which depends on the materials available in the areas surrounding the fields in which they are built. Today, it increasingly depends on the ability to 

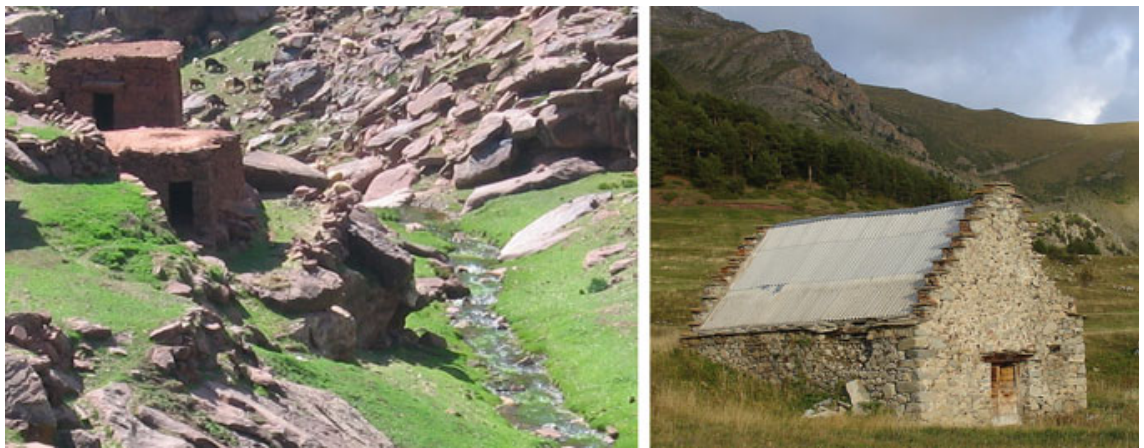

Fig. 5.3 On the left a sheepfold with a horizontal roof in the High Atlas, and on the right a sheepfold with a stepped roof in the Pyrenees

purchase material from the outside (cement, iron, aluminium, etc.), which is more obvious in the Pyrenees where the shepherds are more capitalized, notably as a result of European subventions which support their way of life (even if always insufficiently), whereas in the Moroccan case they are absolutely inexistent (Fig. 5.3).

The construction differences are always linked to both, the biophysical and the sociocultural differences of each context. As can be observed in the two photos above, the Pyrenean example has a roof at an inclination of more than $45^{\circ}$ which contrasts to the completely flat roofs of the High Atlas. This could be directly related to the pluviometric difference between the two areas, with much higher precipitation in the Pyrenees, therefore requiring a much more powerful water and snow runoff system. Nevertheless, unlike the explanation of the over $45^{\circ}$ inclination of the roof in the Pyrenean case, mainly ecologically determined by the need to face high pluviometry and snow, the form of the roof of the Pyrenees sheepfold characteristically formed by "little steps" cropping up the roof, is at the same time related to the technical and aesthetic notions of the French valleys of the northern side of the Pyrenees. In fact, this sheepfold is located only a few kilometres from the French-Spanish border and evidently the shepherds from this region (Sant Juan de Plan) were influenced by the culture of their neighbours. In fact, the shape of these roofs is both identical to constructions from the north face of the Pyrenees and different from the high mountain Spanish sheepfolds in other more southern but much closer neighbouring regions. At the same time, the horizontal roofs of the sheepfolds and houses of the High Atlas, coming from the conditions and techniques of the much drier North African plains, and which have expanded upwards through the slopes of the High Atlas for centuries, up to altitudes at times above $2500 \mathrm{~m}$ and $700 \mathrm{~mm}$ of rainfall and snowfall, are probably partially poorly adapted to the conditions of the north side of the High Atlas of Marrakech, which is quite close to the humid influences of the Atlantic Ocean. Nevertheless, these still survive, in this case not precisely due to bioecological conditions but mainly as a heritage of a particular know-how and aesthetic tradition belonging to a much wider region, that of the greater Maghreb. 


\subsubsection{Spirituality of Euro-African Transhumant Systems}

At the same time, and in their specific forms, approaching both transhumant models as a total social fact enables us to gain a better understanding of the essence of these systems. In other words, to understand all the aspects of the social life of the transhumants and to understand how they reflect the social system of the livestock breeders' communities of origin. In fact, the "transhumance period" sets all the communities in motion and projects all the aspects of the social system onto the space used by the shepherds. Thus, a reduced social and symbolic model of the livestock breeders' community of origin is projected onto the different spaces where transhumance takes place (Mahdi 1999). The highland pastures and the villages are a physical and sociocultural space alike. They are a productive space but also an annual meeting point where livestock breeders and village people socialize and reencounter each other year after year. The perenniality of the transhumant building depends on the answer to a fundamental question: How can a collective discipline be kept to manage these spaces and ensure that they are commonly used by different livestock breeders without becoming a tragedy of common resources (Hardin 1968)? How can the collapse of the common pool be avoided, while preventing or minimizing conflicts between shepherds? In other words, how can the competition between these different users be effectively regulated in this double biophysical and sociocultural perspective?

The results of my different theoretic and field works on the phenomenon of the transhumance conducted over the past decade, reveals a regulation model in which the management institutions quite greatly coincide in the two Mediterranean mountain areas, in the sense that they are at the same time fundamental and structured similarly in managerial assemblies of users, but were traditionally also never isolated from religion and the sacred. The spiritual and the immaterial world have always had a fundamental place in Mediterranean mountain transhumant systems. To portray this, the place of local saints referring to transhumance and highland pastures is a particularly sharp example of this. In fact, we generally find these spaces under the patronage of mythical figures and sanctities that centre the performance of pastoralist and transhumant rituals, in order to ensure a complete and balanced management of the villagers' common lands. Throughout the transition cycle between the arrival of the shepherds to "the villages" and the move up to the high pastures, individual and collective rites, celebrations and ceremonies are performed always in linkage or homage to a local saint, both in the Pyrenees and the High Atlas. There are several examples of hermitages and other places associated with saints where shepherds bring their animals to be blessed or where saints are honoured. Through these rituals the livestock breeders seek to safeguard the collective and individual assets, to protect the livestock and to bring prosperity and fertility to their animals and community.

The place of saints in tribal Moroccan and North African societies is well-known. The livestock breeders placed, and often still place their herds under the protection of a saint. The saint guaranteed fertility, protection (particularly 
against spirits and devils), and prosperity for the livestock, and in exchange, the livestock breeders gave thanks to the saint in the form of gifts and sacrifices. Gellner (1969) showed particularly well how, according to their physical location and that of their sanctuary, on the border between tribes, the saints and their families acted as arbitrators in conflicts, bringing about agreements, assisting traders in times of war and guaranteeing the safety of passages (Gellner 1981). For example, the pastures of Oukaïmeden and the Yagur are, respectively, placed under the patronage of the saints Sidi Fars and Sidi Boujemaa. By analysing the histories of different Maghreb saints, theoretically forbidden by the most orthodox Islam, and less present in the Machriq, we observe a sacralisation of pacts and discipline regarding the use of pastures being established, distributing rights to groups and establishing the tithes and sacrifices that the livestock breeders must make annually before, during and after transhumance. The regulation of the pastures, with their opening and closing dates, is thus linked to the saint and their descendants who are themselves a saint caste, announcing the day on which the pastures would open, thereby sacralising, legitimizing and reinforcing the respect for the regulations that pend upon these common pastures.

At the same time, although such a lineage of saints acting as arbitrators never seems to have existed in the case of the Pyrenees, at least not within historic times, after the period in which shepherds were traditionally excluded from the village, when they had left for the plains, and just before moving up to the highland pastures, the shepherds lived a time of celebration, joy and reunion between shepherds and their families, neighbours and friends that very often matched with key religious dates (Nadal et al. 2010). This is still celebrated today, on the anniversary of the specific saint of each community, giving a ritual and sacred nature to the entry of the animals to the collective highland pastures immediately after. Among other things this was set up to express that a lack of respect for the exclusion of animals before the key date was serious and dangerous. As in the High Atlas, the saints, in other words, God's emissaries, were always there to remind us of the rules and good pastoral conducts. Likewise, livestock breeders in the Pyrenees turn to and notably turned to a huge number of saints (San Urbez, San Visorio, San Victorián, Santa Orosia, Santa Elena, San Cosme, San Damián, San Martín, Santa Marina) and to different apparitions of the Virgin at some of the different key moments of their transhumant cycle. If honoured according to the correct rituals, these figures were able to ward off the dangerous action of sorcerers (Pallaruelo 1988, pp. 196, 194). In this sense, the opening of the pastures in the Pyrenees is often also lived as a festivity of homage to one of the patron saints of the village, and thereby structuring the whole Pyrenees pastoral calendar, in which the entertainment and socializing is nevertheless, often even more important than the religious sense for local populations (Villa 1988), as it seems to happen very often too in the Moroccan cases (Dominguez 2010). The passage from one cycle to another, that is, from "life in the lowlands" to "life in the highlands", is frequently initiated by a village celebration starting at the moment that the shepherds arrive, or simply just before moving up to the highland pastures if they do not migrate to the plains anymore. This is undertaken at a place of pilgrimage, like a hermitage or a 
place where we find the reference to a local saint, through the celebration of a collective meal in which several small ruminants, often sheep, are sacrificed and offered to the community with fresh cheese produced during these celebratory days. Thus, by bringing together all the representatives of the community around very precise dates linked both to the saints and the transhumance, by bringing children and adults together through a convivial collective activity of sharing and harmony, these meals and celebrations refer both to the social structures and functions of the community particular to each human and ecological environment, as well as to the rules and values of pastoral cohabitation and inter-solidarity, since this time also serves to recall them and to update them through the different rituals each new year (Beltrán 1993, pp. 364-366; López 2010, p. 153).

One of the points that seems most significant to me regarding the divergence between the two models of this saint and religious management of the transhumance and the plant communities that it affects in the highland pastures, is the different denominational traditions of each type of transhumants, one Catholic Christian and the other Sunni Muslim. In this case, the ethnographies available show us diverse forms of beliefs on highland pastoral areas and their management. In Morocco, if the collective rule is not respected, they manifest in particular in the omnipresent threat of spirits or devils, representations notably rooted in the Koranic tradition (Mahdi 1999). At the same time, in the case of the Pyrenees, it is in the form of witches serving Lucifer, which pastoral behaviour is threatened and conditioned, beliefs linked in turn to a different European-biblical tradition (Pallaruelo 1988).

At the same time, the most fundamental biocultural or eco-anthropological convergence that can be found between the High Atlas and the Pyrenees in this arena of magical-religious management of shared pastures, is that to a great extent, magic and/or the sacred pervaded the majority of precautions, management and remedies applied by shepherds in the management of their land and flocks. Since the transhumants were obliged to live in inhospitable, solitary and at times dangerous places, always threatened by wild animals, verticality and typical the storms of high Mediterranean mountains, as well as to ensure an increase in their flock and boost the fertility of these, on which their life and that of their community depended, the shepherds used their traditional ecological knowledge, passed, tested and constantly updated from generation to generation, but also their spiritual knowledge and religious beliefs. Through these shared characteristics of their biophysical and sociocultural means of production, which surpassed many times their capacity to control the different unexpected events at each time, particularly high in the oro-Mediterranean pastoral context, both Berber and European livestock breeders faced uncertainty and risk with a rich cosmology of the spiritual world.

All the components of these hagiographic transhumant models are not always found in each case studied, not when comparing the High Atlas and the Pyrenees, nor when comparing different communities within each of these two macro-units. Clearly they are never expressed in the same way because they always depend on the particular history and geography of each case. Even from one side of a valley to the other, the versions of one same hagiographic story can vary .... And so, from one mountain range to another, even more. Thus, variants meet passing from one 
situation to another, diversifying with the biophysical settings and the particular social histories of each group of transhumants. And nevertheless, they do not exclude the existence of astonishingly close elements, almost shared in their most essential nature, as we have seen. In short, in both cases, transhumance to pastures is an opportunity for the organization of social, economic, political and religious activity, which participates, consolidates and even rules great part of the collective discipline, accompanying the success of this model of management of natural resources, while co-determining with the local ecological conditions a rather particular socio-ecosystem built for and by each community. Transhumance to pastures is multidimensional; seeing it just as folklore is to overlook a type of social organization where spirituality, the sacred, has an important place and gives material activities a lot of their meaning. Likewise, only focusing on the ecological effects of pastoralism or on an antiquated mono-directional and functionalist determinism of the environment over human culture, would be forgetting other factors that determine or condition this same environment and that are born out of other type of interactions too, also out of human interaction and cultural exchanges.

\subsection{Conclusions}

With the view of contributing to deepen in the study of the biocultural bond and the different forms that it adopts, study which is still only emerging and is very rarely approached from the humanities or a broad perspective in social science, the present text has explored different links between natural and cultural attributes of two transhumant mountain systems, attempting to open towards such broader analytic lenses. At the same time similarly and differently, transhumance still exists in these mountain ranges of the Western Mediterranean region, the central Pyrenees in Spain, and the High Atlas in Morocco. In the Spanish case, like in other European countries, transhumance has undergone a very severe process of degradation and decline, particularly during the last one hundred and fifty years, mainly due to the communal land seizures and enclosure processes imposed by central states with the aim of assuring public control over natural resources or land privatization within global capitalist dynamics, feeding the industrialization of the nineteenth and early twentieth centuries, but which increasingly imposed obstacles on the fragile and costly mobility of the flocks through their transhumance, traditionally of several hundreds of kilometres. This favoured the abandonment of rural areas, the agricultural intensification of private corporations and the subsequent countryside re-urbanization in the more recent years (MacDonald et al. 2000; Stoate et al. 2001; Uhel 2006).

With the goal of implementing a particularly rich comparative approach of a world that has been for long time declining in the Pyrenean case, the inclusion of a study of Moroccan transhumant systems is related to the fact that it helps to understand the history of the former (the Pyrenean), since contrary to what happened in Europe, in Southern Mediterranean countries transhumance has not suffered such intense, systematized and widespread communal land seizures or 
enclosure processes as those in Europe. In fact, most High Atlas transhumant systems, although not free from increasingly external impositions and also intensely modified, are still highly traditional and a main agro-pastoral management tool for highland communities and economies (Auclair and Al-Ifriqui 2012). They follow demographic evolutions that are very different from the decay or abandonment of mountain areas in Europe and are in constant and rapid re-adaptation to the continuous social and environmental changes. Hence, even if the adaptive processes undertaken by the two different transhumant models are not in any case symmetrical nor fully predictable, the present text has shown how exploring comparatively the two cases from a detailed historical, ethnographic and eco-anthropological point of view among others, helps to further our understanding of certain aspects of their biocultural diversity and its genesis, while providing us with examples of organizational systems which we can still trace and which we should examine more holistically. This is, including the humanities and a wider spectrum of the social sciences in their interaction with the environmental sciences, when asking ourselves about the possible ways of assessing, conserving and/or adding value to biocultural diversity.

\section{References}

Alaoui S (2009) Les pelouses humides dans le haut Atlas: Biodiversité végétale, dynamique spatiale et pratiques de gestion coutumière. Dissertation, Université Cadi Ayyad

Almagro M (1942) La Cultura megalítica en el Alto Aragón. Ampurias 4:155-169

Auclair L, Al-Ifriqui M (2005) Les agdals du Haut Atlas marocain. Enjeux d'une recherche pluridisciplinaire. Cahiers de Recherche du Centre Jacques Berque 3:60-79

Auclair L, Al-Ifriqui M (ed) (2012) Agdals. Society and resource management in the Moroccan Atlas. Royal Institute of Amazigh Culture - Institute of Research for Development, Rabat

Barbera G, Cullotta S (2012) An inventory approach to the assessment of main traditional landscapes in Sicily (Central Mediterranean Basin). Landscape Res. doi:10.1080/01426397. 2011.607925

Bellaoui A (1989) Les pays de l'Adrar-n-Dern. Etude géographique du Haut Atlas de Marrakech. Dissertation, Université de Tours

Beltrán O (1993) Es Aranesi: adaptació a l'entorn i organització social al Pirineu central. Dissertation, Universitat de Barcelona

Braudel F (1949) La Méditerranée et le Monde Méditerranéen a l'époque de Philippe II. A. Colin, Paris

Chassany JP (ed) (2008) Les paysages culturels de l'agropastoralisme, méditerranéen edn. Conseil général de l'Aveyron, Meyrueis

Clot A (1974) El arte gráfico prehistórico en los Altos Pirineos. MUNIBE (Sociedad de Ciencias Naturales ARANZADI) 1-2:57-62

Dominguez P (2010) Approche multidisciplinaire d'un système traditionnel de gestion des ressources naturelles communautaires: L'agdal pastoral du Yagur (Haut Atlas marocain). Dissertation, École des Hautes Études en Sciences Sociales/Universitat Autònoma de Barcelona

Dominguez P, Hammi S, (2010) L'agdal du Yagur, écologie et pastoralisme. In: Fernandez K (ed) Ecología y Pastoralismo, Koldo Michelena, San Sebastián, p 34-56 
Dominguez P, Bourbouze A, Demay S, Genin D, Kosoy N (2012) Culturally mediated provision of ecosystem services: the agdal of Yagur. Environ Values 21:277-296

Fillat F, García-González R, Gómez D (1995) Importancia de la ganadería en la conservación del paisaje pirenaico. Quercus 107:24-26

Fillat F, García-González R, Gómez D, Reiné R (eds) (2007) Pastos del Pirineo. CSIC, Madrid

Gellner E (1969) Saints of the Atlas. Weidenfeld and Nicolson, London

Gellner E (1981) Muslim society. Cambridge University Press, Cambridge

Gómez-Baggethun E, Mingorría S, Reyes-García V, Calvet L, Montes C (2010) Traditional ecological knowledge trends in the transition to a market economy: empirical study in the Donana natural areas. Conserv Biol 24(3):721-729

Hammi S, Al-Ifriqui M, Simonneaux V, Auclair L, Montes N (2007) Évolution des recouvrements forestiers et de l'occupation des sols entre 1964 et 2002 dans la haute vallée des Ait Bouguemez (Haut Atlas Central, Maroc). Sécheresse 18(4):271-277

Hardin G (1968) The tragedy of the commons. The population problem has no technical solution; it requires a fundamental extension in morality. Science 162(859):1243-1248

Jiménez J (2006) La imagen de los espacios de alta montaña en la prehistoria: El caso de los Pirineos Catalanes Occidentales. Dissertation, Unversitat Autònoma de Barcelona

Joint programme on the links between biological and cultural diversity. 2010

Loh J, Harmon D (2005) A global index of biocultural diversity. Ecol Ind 5(3):231-241

López JD (2010) Las fiestas de la primavera: bienvenida a los pastores trashumantes. In: Vidal P, Castán JL (ed) Transhumancia en el Mediterráneo, Ceddar, Zaragoza

MacDonald D, Crabtree JR, Wiesinger G, Dax T, Stamou N, Fleury P, Gutierrez-Lazpita J, Gibon A (2000) Agricultural abandonment in mountain areas of Europe: environmental consequences and policy response. J Environ Manage 59:47-69

Maffi L (2005) Linguistic, cultural, and biological diversity. Annu Rev Anthropol 29:599-617

Mahdi M (1999) Pasteurs de 1'Atlas. Production pastorale, droit et rituel, Ed. Fondation Konrad Adenauer, Casablanca

Maluquer J (1987) La població prehistórica a la Vall de Serradell. Collegats 1:31-44

Mauss M (2012 [1925]) Essai sur le don. Forme et raison de l'échange dans les sociétés archaïques. PUF, Paris

Mazzucco N, Gassiot E, Rodríguez D, García D, Obea L (2012) Les primeres comunitats ramaderes de la Vall de Sant Nicolau (5.000-2.300 CalANE). In: Aniz MM (ed.) IX Jornades sobre Recerca al Parc Nacional d'Aigüestortes i Estany de Sant Maurici, Ed. Generalitat de Catalunya \& Parc Nacional d'Aigüestortes i Estany de Sant Maurici, Lleida, pp 221-233

Mcneil JR (2003) The mountains of the Mediterranean world. An environmental history. Cambridge University Press, Cambridge

Mittermeier R (2004) Hotspots revisited: Earth's biologically richest and most endangered terrestrial ecoregions. Cemex, Mexico

Nadal E, Igleias J, Estrada F (2010) Generalitat de Catalunya. Departament de Cultura, Barcelona

Pallaruelo S (1988) Pastores del Pirineo. Ministerio de Cultura, Madrid

Pascon P (1983) Le Haouz de Marrakch. CURS-CNRS-INAV, Rabat

Rasse M (2008) La diffusion du Néolithique en Europe (7000-5000 av. J.-C.) et sa représentation cartographique. Mappemonde. http://mappemonde.mgm.fr/num18/articles/art08205.pdf. Accessed 27 Jan 2015

Rodrigue A (1999) L'art rupestre du Haut Atlas marocain. L'Harmattan, Paris

Sellier E (2004) L'agdal du Yagour. Territorialités au pluriel pour la protection de la nature dans le Haut Atlas de Marrakech. Dissertation, Université de Provence

Simoneau A (1967) Les gravures du Haut Atlas de Marrakech. Revue de Géographie du Maroc 11:67-76

Sirami C, Nespoulous A, Cheylan JP, Martya P, Hvenegaarda GT, Geniezh P, Schatza B, Martin JL (2010) Long term social and ecological dynamics of a Mediterranean landscape: impacts on biodiversity. Landscape and Urban Plan 96:214-223

Stepp R (2005) Mountains and biocultural diversity. Mt Res Dev 25(3):223-227 
Stoate C, Boatman ND, Borralho RJ, Rio Carvalho C, de Snoo GR, Eden P (2001) Ecological impacts of arable intensification in Europe. J Environ Manage 63:337-365

Sutherland WJ (2003) Parallel extinction risk and global distribution of languages and species. Nature 423:276-279

Uhel R (coord) (2006). Urban sprawl in Europe: the ignored challenge. EAA Report 10(2):56

Vidal P, Castán JL (eds) (2010) Transhumancia en el, Mediterráneo edn. Ceddar, Zaragoza

Villa J (1988) Una reflexión sobre la fiesta, el rito y la danza en las Comunidades Pirenaicas. Revista El Gurrión 32:8-12

Zent S (2001) Acculturation and ethnobotanical knowledge loss among the Piaroa of Venezuela: demonstration of a quantitative method for the empirical study of traditional ecological knowledge change. In: Maffi L (ed) On Biocultural diversity: linking language, knowledge and the environment. Smithsonian Institution Press, Washington 